\title{
ACHIEVING FAMILY FARMERS' DEMANDS FOR MICROCREDIT THROUGH CREDIT UNIONS: A FRAMEWORK FOR DISCUSSION
}

\author{
TANIA PEREIRA CHRISTOPOULOS \\ Universidade de São Paulo (USP), São Paulo - SP, Brazil. \\ LAURO GONZALEZ \\ Fundação Getúlio Vargas (FGV), São Paulo - SP, Brazil.
}

To cite this paper: Christopoulos, T. P., \& Gonzalez, L. (2017). Achieving family farmers demands for microcredit through credit unions - a framework for discussion. Revista de Administração Mackenzie, 18(5), 116-143. doi 10.1590/1678-69712017/administracao.v18n5p116-143 


\section{ABSTRACT}

Purpose: This study aims to analyze a model of credit union, which allows meeting demands of microcredit of family farmers in a responsible way, identifying the real needs of clients and promoting financial access.

Originality/value: In recent years, the microfinance community has witnessed unwanted consequences of microcredit misuse. We present an original approach about the way credit unions may achieve their target in a responsible way, offering appropriate products, services and training to the entire community involved.

Design/methodology/approach: Through secondary data and interviews with decision makers and credit union members, we studied the case of Cresol Baser, a large credit union in Brazil. We analyzed data based on inductive theorizing. First and second-order themes were identified, resulting in a procedural model, representing relationships between responsible microfinance factors.

Findings: The three main dimensions in the model of inclusive microfinance - conditions, proximity, and access - were integrated in order to promote a dynamic that respects the assumption of a responsible financial inclusion with regards to design, offer and access of products and services related to microfinance.

\section{KEYWORDS}

Responsible microfinance. Credit union. Microcredit demands. Proximity. Family farmers. 


\section{INTRODUCTION}

Data from World Bank reports that around 2.5-billion working-age adults globally live without access to the types of financial services we take for granted. Without these services, they rely on informal mechanisms that tend to worsen their already deprived economic situation (Ledgerwood, Earne, \& Candace, 2013). This so-called "financial exclusion" contributes to the increase of inequality and hinders social development (Demirguc-Kunt \& Klapper, 2012).

Building financial inclusiveness requires more than institutional expansion and portfolio growing, as occurred over the last decades. It also comprises equipping and informing clients on how to use products and services. Over the last decades, the field of microfinance has changed considerably. The narrow focus on the institution and its performance that endured since the seventies has changed to a much broader focus on clients. Understanding their behavior, identifying financial service needs, and finding ways to better meet these needs have being some of the concerns of researchers, governments and private institutions (Ledgerwood, Earne, \& Candace, 2013).

One of the main reasons has been that the impact of provided microfinance services - mainly microcredit - has not been as expected. Over the last decades, microcredit has brought hope for its contribution to reduce the world poverty, but in the last years it has found adverse reactions due to unexpected and unwanted consequences such as over indebtedness (Banerjee, Duflo, Glennester, \& Kinnan, 2013). These unwanted effects also brought other problems such as the perception that microcredit is the largest risk among industry possibilities (CSFI, 2014). As a consequence, banks have created additional requirements and have less flexibility to extend credit, prioritizing customers with potential lower default rates (Pimentel \& Kerstenetzky, 2008).

One alternative to reduce the potential risk is the logic of "finance proximity". Defined as both geographic and social proximity between borrowers and financial institutions via direct and permanent contact with credit agents, it has been pointed out as an opportunity to improve the focus on clients (Búrigo, 2006). This opportunity seems promising, and currently found its application on the non-traditional financial system, represented by credit unions, public interest non-governmental organizations, NGOs or development banks. 
One interesting example of an organization that adopts this geographical approach is that of Brazilian credit unions. Data from the Central Bank of Brazil show that these organizations already have a relevant and growing participation in the Brazilian Financial System. The volume of microcredit provided by credit unions represents $6.1 \%$ of the total microcredit financial system (Banco Central do Brasil [BCB], 2015a). Moreover the number of credit union members jumped from 4.2 million members in 2010 to 7,5 million in 2015 (BCB, 2015b) and over 1,146 credit unions around the country (BCB, 2015).

Furthermore, the new regulation - Resolution No. 3.106/03, in which the National Monetary Council redeemed and standardized the system of free admission - broadens the possible ways of association, allowed that one credit union be formed by members of different professional fields. Until December of 2004, the group of credit unions was basically composed of clusters called "individual credit unions", which in turn were composed only of members from the same activity sector (Chaves, 2004). Granting loans to this new type of institution increased the total credit concession from $48 \%$ in 2010 to $62 \%$ in 2014, representing almost two thirds of segment awards (BCB, 2015, p. 93).

Despite of Meinen (2013) arguments who sees free admission as the only way to build sustainable credit unions in less densely populated areas, free admission credit unions do not seem to use their potential of promoting inclusion in less densely populated areas - there were less than 20 free admission credit unions in the North and Northeast regions - the less developed regions in the country, compared to 44 in the Center-West (Kalliala, 2016).

By understanding customers' behavior, proximity with local needs contributes to the provision of microcredit practices closer to their needs. This is especially relevant for the success of microcredit, closely linked to the ability to correctly rating the credit risk of the borrower, in most cases not able to offer guaranties. As a result of their corporate structure and associative nature, credit unions have clear comparative advantages with regard to knowledge of the borrower. Finance proximity stimulates the mobilization of savings, investment and local planning, which are aspects not regularly championed by the banking system. The greatest virtue of this system is that it creates networks that generate social capital and awakens economic initiatives that banks would not have the will to grant (Abramovay, in press).

In spite of the aforementioned potential of credit unions in providing microcredit according to new scenario demands, there is a lack of studies that 
show empirically the role they play (Gonzalez \& Brito, 2013). This article aims to contribute to filling this gap. The specific objective is to analyze how a credit union can achieve microcredit demands, in a responsible fashion, by identifying the real clients' needs and understanding their behavior. We will study the case of Cresol Baser, one of the biggest credit unions in Brazil, located in the south region of the country.

After the introduction, the next sections of this paper present a literature review of microcredit and credit unions, analyzing their characteristics and history. Then the paper describes the Cresol credit union business model for family farmers and the adoption of a responsible financial inclusive attitude. After that, the paper describes the methodological approach, presents the findings and our main contribution in this paper, an inductive framework for discussion. The last section brings the final considerations.

\section{MICROCREDIT EVOLUTION TOWARDS A RESPONSIBLE APPROACH}

Microfinance can be defined as the supply of financial services to lowincome individuals who are usually excluded from the traditional financial system by using a different methodology. Microcredit also refers to small loans borrowed within the broader perspective of microfinance (Monzoni Neto, 2006; Morduch, 1999; Righetti, 2008).

The term microcredit emerged in the 1970s with the creation of relevant innovations that revolutionized the way of supplying credit in small scale to poor people in a more responsible fashion. High risk, high transaction costs, and lack of collateral were overcome by the adoption of a set of important innovations that sought to facilitate the supply of credit to the poor. Armendáriz de Aghion and Morduch (2010) discuss these innovations - the concept of group lending; the employment of local agents; the progressive increase in loan values; and the increase in the frequency of repayments.

Group lendings are arrangements made by individuals without collateral who form groups with the aim of obtaining loans from a lender. The great advantage of group lending is dealing with the problem of information asymmetry and high transaction costs (Karlan, 2007; Morduch, 1999).

The employment of local informed agents to collect data related to borrowers as well as monitoring and providing assistance to customers, technical reports analysis, and closer monitoring of the portfolio made them 
primarily responsible for the insertion of microcredit in a given community (Fachini, 2005).

The progressive increase in loan values provides a fundamental and dynamic incentive in relation to microcredit risk management. Typically, loans start with low values and, when there is a record of regular payments, the amounts increase. The repetition of operations allows accumulation of customer information and increases customers' credibility in the system (Armendáriz de Aghion \& Morduch, 2010).

Finally, the increase in frequency of repayments innovates when considering the cash flow of the funded projects. Many microfinance institutions collect payments weekly or fortnightly, which is logical considering the cash cycle of trade activities and services of microentrepreneurs (Morduch, 1999).

Concerning the responsible microfinance approach, other authors pointed out towards democratization and outreach such as Hulme and Arun (2011) or to preventing non-ethical behavior such as Reinhard (2008). Hulme and Arun (2011) propose measures to correct some issues that have been posing microfinance under attack for failing to help the poor, treating its clients badly, charging high interest rates and encouraging poor people to take on excessive debt burdens. Among these measures, they suggest the democratization of banking services, provision of secure savings facilities for poor people, and social benefits, emphasizing women's needs. Reinhard (2008) emphasizes that, in the microfinance field, the conflicts between commercial and developmental aspirations are not inevitable, suggesting that there are ways to combine them using the strengths of the capital market and, at the same time, maintaining developmental focus and importance. This is especially important in the case of credit unions that change their models such as the case of Cresol, which is now allowing the participation of new members without bonds.

\section{CREDIT UNION BUSINESS MODELS}

The origin of credit unions has similarities with the origins of microcredit. The first credit union emerged in Germany, in 1847 (Pinheiro, 2008). They emerged in response to perceived failures in the traditional financial system, pervading the spaces where banks could not work (McKillop \& Wilson, 2010). After the First Industrial Revolution, traditional banks expanded, investing mostly in large-scale projects. Workers' access to savings and loans was scarce (Singer, 2002). As a response, credit unions spread throughout Europe and North America. 
Some business models of credit unions are emblematic. Among them, there are Luzzzati's and Desjardins'. Luzzati's model was created in Italy, and it was the first credit union without any common bond between the members, since they did not necessarily need to belong to a similar trading sector or even live in the same region. Luzzatti's type of credit union was so flexible that even allowed the possibility of granting credit to nonmembers. Another relevant credit union model was implemented by Alfonse Desjardins. Desjardins credit unions were created in Canada in 1900 as a way to support the development of francophone communities. Differently from Luzzati's model, it required that all members have a common bond (Búrigo, 2006).

In Brazil, credit unions appeared in 1902, in the southern part of the country, inspired by a German model called Raiffeisen. The model involved free admission and was typically rural, involving the several responsibility of members, one man - one vote and no dividend (Pinheiro, 2008). This characteristic of free admissibility was banned by Law no. 4.595/64, hindering their operation. The situation became more flexible only in the late 1980s, when the Central Bank relaxed requirements for credit unions (Lhacer, 2012).

The new conditions enabled growth and, in the 1990s, Brazil saw the consolidation of small credit unions in larger organizations and the emergence of new ones: Sicredi, which is comprised mostly of rural credit unions in the South; Sicoob, which aggregates mutual credit unions and credit unions in the Northeast; and Unicred, which includes health professionals' credit unions. Both Sicredi and Sicoob manage their own cooperative banks. Cooperative banks enable these systems to act directly in the interbank market and participate in the Brazilian payment system. Distinct from these models, the Confesol (Confederation of Central Rural Credit Unions with Solidarity Interaction) - was created based on the principles of solidarity economy (Lhacer, 2012).

In terms of structure, credit unions are divided into: 1) individual credit unions that provide financial and credit services only to its members, receiving transfers from other financial institutions and making investments in the financial market; 2) centrals, which provide services to affiliated individual credit unions, and are also responsible for their supervision; 3 ) confederations of central cooperatives, which provide services to centrals and their affiliates (Pinheiro Neto Advogados, 2015) 


\section{THE CRESOL CREDIT UNION AND THE ADOPTION OF A RESPONSIBLE FINANCIAL MODEL FOR FAMILY FARMING INCLUSION}

Under the Confesol confederation umbrella, in 1996, the Cresol Baser central was created, in Francisco Beltrão, a rural municipality of Paraná, located in the southwestern region of Brazil, to centralize assistance to already existing individual cooperatives.

Nowadays, the Cresol system is organized in a set of individual credit unions and regional bases. The individual credit unions have their local financial agents working directly with the members (farmers); and regional bases are organized by geographic areas to assist and control the work of individual credit unions. These agents also coordinate the overall organization and political representation, working mainly on the supervision and control systems. Cresol's mission is "to promote the social inclusion of family farming by providing access to credit, savings products and appropriation of knowledge, aiming at local development and institutional sustainability" (CRESOL, 2013a).

For the last several years, Cresol has been structured and achieved growth. Since 2001, it has enlarged its activities and outreach by providing advice for new initiatives of solidarity credit unions in other regions of Brazil. In 2014, Cresol released $\mathrm{R} \$ 346$ million as microcredit, and $\mathrm{R} \$ 577$ million as solidarity credit with its own resources (CRESOL, 2014a). The amount is small if compared with the total volume of microcredit in Brazil in 2013-6.2 billion Reais (BCB, 2015a), but its inclusive potential lies on the opportunity provided to individuals who do not have accounts at another bank.

The cooperative segment covered 5.5 million cooperative members in 2012, concentrated in the South and Southeast, according to the Cooperative Census data of 2012. Despite representing only $4 \%$ of the adult population, the cooperative data demonstrate that unions have inclusive potential, confirmed by the percentage of $43 \%$ of the members who do not have accounts at another bank (BCB 2015). Besides, data show that the loans granted by cooperatives to individuals have grown faster than on the National Financial System. In the last five years (2010-2014), credits granted by credit unions and by other financial institutions achieved $128 \%$ and $76 \%$ of the total, respectively (BCB, 2015).

On the other hand, it is noteworthy to mention that credit unions have still a huge space to grow. In spite of the fact that, over the last decade, microcredit volume has increased in more than $900 \%$ (Lhacer, 2012, p. 50), 
only 73 out of 1161 cooperatives have provided microcredit. Moreover, the segment of credit unions accounts for $6.1 \%$ of the total portfolio of credit in Brazil, $3.9 \%$ of the number of operations and $5.1 \%$ of the amount of microcredit clients. The operations are concentrated in four credit unions institutions, which account for $81.6 \%$ of the portfolio amount and $84.9 \%$ of the segment's operations (BCB, 2015a).

As this article aims at analyzing how a credit union can achieve microcredit demands, in a responsible fashion, by identifying the real clients' needs and understanding their behavior, we will now identify some criteria that will enable the evaluation of responsible financial inclusiveness. Financial inclusion considers not only the availability of a product or service, but also the accessibility and financial information/education. Inspired by Helms (2006) the products and services will be described as inclusive in terms of four aspects: (1) whether the organization knows the customers and their needs and therefore designs and offer products and services that meet these needs (2) product access, (3) the consumer's ability to properly use the product and (4) the atmosphere around the operations of microfinance institutions and banks, which considers regulation to facilitate financial inclusiveness. These aspects will be applied in the case study analyzed in this research and will inspire the creation of an inductive framework for future analysis.

\section{METHODOLOGY}

Our research approach will be based on the case study of Cresol Baser. The case was selected since it is unique. In Brazil, there are not many similar situations - credit unions acting as official agents to transfer resources from the government and, at the same time, operating under solidarity bonds and providing a range of services and products based on the "proximity" concept. The uniqueness of this situation justifies the choice for a single case study approach (Stake, 2000).

During the first phase, data were collected from documents - financial reports and web sites. The study analyzed financial reports from 2009 to 2014. This process resulted in a large amount of data we used to respond to the four concepts related to responsible financial inclusion, defined from Helms (2006) theory.

In that sense, the second phase of our data collection consisted of in-depth interviews with decision makers. In order to be thorough and provide credibility to available information as recommended by Eisner (1991), we 
interviewed users, advisors and two members from the board. We conducted the interviews on November, 2013. Each interview lasted about two hours. The interview script was created focusing on the objective of investigating if the products and services were designed and offered on a responsible financial inclusive way, following the guidelines proposed by the theory.

The first aspect investigated was the capacity of products and services to meet the demand needs (Helms, 2006). The interview questions tried to verify the existence and application of tools to understand clients' needs and their satisfaction degree regarding products and services offered.

Another point of analysis was the access to products offered by the institution, that is, whether the previously developed products were able to reach its target audience (Helms, 2006). To understand how the developed products were accessed in the various territories, the question was about which distribution channels were used and what was the public acceptance for each of them (Fonseca, Meirelles, \& Diniz, 2010).

The consumer's ability to properly use the product (OCDE, 2004) another important aspect in research on inclusive products - was explored through questions about the existence of training on financial education to members and, if it exists, how it works, what is the frequency and how many cooperative members have taken part in it.

The last aspect investigated was the macro environment (Helms, 2006). Questions were about facilities (or barriers) the government has created for cooperative action in recent years and which regulations help or hinder the development of the cooperative work. Questions about partnerships were included in this topic, since they are part of the macro environment.

\section{RESULTS}

The material was analyzed in light of the theory guiding the responsible microfinance approach (Helms, 2006) and, as a result, a framework was created to explain all the reciprocal relations between the four explored aspects.

\section{First aspect: Whether the organization knows the customers and their needs and therefore designs and offer products and services that meet these needs}

According to one of the decision makers in charge of the insurance department, what differentiates Cresol from traditional banks is the personal 
approach through 720 local agents and credit analysts, who evaluate the needs of clients. Local agents assess what local needs are, and what products and services are appropriate to meet them. Local agents' findings provide elements that inspire the creation of new products or services and their implementation. Credit analysts work on the implementation of these new products in individual credit unions after being trained based on financial agents' information.

Among the financial products and services offered by Cresol, it stands up PRONAF (National Program for the Strengthening of Family Farming Programa Nacional de Fortalecimento da Agricultura Familiar). This program is currently granting $\mathrm{R} \$ 28.9$ billion and products are designed to achieve different needs, as reported in table 1 (Ministério do Desenvolvimento Agrário, 2015).

\section{(Table 1)}

PRODUCTS AND PROGRAMS OFFERED BY THE CRESOL SYSTEM

\begin{tabular}{|c|c|c|c|c|}
\hline $\begin{array}{l}\text { Lending } \\
\text { programs }\end{array}$ & $\begin{array}{l}\text { Products } \\
\text { related to } \\
\text { environmental } \\
\text { variables }\end{array}$ & $\begin{array}{l}\text { Synergies with } \\
\text { governmental } \\
\text { programs }\end{array}$ & $\begin{array}{l}\text { Other banking } \\
\text { and non-banking } \\
\text { services }\end{array}$ & $\begin{array}{l}\text { Disaster relief } \\
\text { products }\end{array}$ \\
\hline Pronaf Funding & PACDC & PGPAF & $\begin{array}{l}\text { Current/savings } \\
\text { account }\end{array}$ & Credit life insurance \\
\hline $\begin{array}{l}\text { Pronaf More } \\
\text { Food }\end{array}$ & Pronaf forest & Pnae & Education & Collective insurance \\
\hline $\begin{array}{l}\text { Pronaf } \\
\text { Agroindusty }\end{array}$ & Pronaf Eco & PAA & Credit card & Life insurance \\
\hline Pronaf Women & $\begin{array}{l}\text { Pronaf } \\
\text { Agroecology }\end{array}$ & Ater & Check & Car insurance \\
\hline Pronaf Youth & & Proagro & Pension payment & Business insurance \\
\hline Microcredit & & Seaf & Payment services & Motorbike insurance \\
\hline \multirow[t]{3}{*}{ Solcredi } & & & $\begin{array}{l}\text { Mobile phone } \\
\text { services }\end{array}$ & Multi-risk insurance \\
\hline & & & Habitasol & Machinery insurance \\
\hline & & & $\begin{array}{l}\text { Gender and } \\
\text { generation }\end{array}$ & $\begin{array}{l}\text { Hail and Fronst } \\
\text { insurance } \\
\text { Livestock insurance }\end{array}$ \\
\hline
\end{tabular}

Source: Adapted from Gonzalez; Barbosa and Magnus (2015). 
Lending programs encompass different needs, from agricultural environmental. Pronaf Funding for family farmers with annual gross income up to $\mathrm{R} \$ 360,000$ who want to invest on agricultural, forestry and fishery and other lines are focused on investment, such as the ones designed to fund projects of production and productivity raising; Pronaf Agroindustry focused on rural family businesses; Pronaf Women, and Pronaf Youth invest on agricultural activities, rural tourism, crafts and other activities in rural areas. There are also programs related to environment sustainability, such as Pronaf Forest, and Pronaf Eco (Ministério do Desenvolvimento Agrário, 2015).

For Pronaf Funding, More Food, Agroindustry, Women and Youth credit line interests range according to the value required, respecting a regressive criterion: for loans of up to $\mathrm{R} \$ 10,000$ at $2.5 \%$ annual interest rates, loans from $\mathrm{R} \$ 10,000$ to $\mathrm{R} \$ 30,000$ at $4.5 \%$ annual interest rate, and loans ranging from $\mathrm{R} \$ 30,000$ to $\mathrm{R} \$ 100,000$ at $5.5 \%$ annual interest rate. Specific credit lines of microcredit such as some focused on women or on the semiarid lands may have loans with interest rates ranging from $0,5 \%$ to $1,5 \%$ (Ministério do Desenvolvimento Agrário, 2015). These rates are very low when compared with Brazilian commercial banks credit line rates, varying from $11 \%$ to $60 \%$ a year (BCB, 2015).

Loan terms may vary between 1 and 20 years depending on the typology of the financed activity. PRONAF long-term loans meet demands of investments in productive infrastructure of family agricultural property. Through this facility, individual projects of up to $\mathrm{R} \$ 150,000$ and collective projects of up to $\mathrm{R} \$ 750,000$ are funded, with an up to three-year grace period and up to twenty years to pay (Ministério do Desenvolvimento Agrário, 2015).

In addition to Pronaf, there are other governmental programs in which Cresol participates as intermediary, by transferring resources to users (Table 1). Complementary solutions are also offered by Cresol, such as the Microcredit and the Solcredi programs (Chart 1). Microcredit is offered to beneficiaries whose annual family income does not exceed $\mathrm{R} \$ 20,000$ and do not have permanent wage labors. Solcredi is civil society organization, established by Cresol in 2014. Its program focuses on members no longer engaged in agricultural activities, therefore ineligible to access Pronaf funds (Cresol, 2013c). Habitasol is a solidarity housing program started in 2004, giving advantages for financing low cost houses (Cresol, 2013c).

In order to provide solutions to protect family farmers' assets, insurance products are available through Cresol Insurance products (Table 1). Access 
is available to those who intend to protect not only their crop, but also other goods. Saving schemes are intended for enhancing the resilience of clients ahead of unexpected events (Gonzalez, Diniz, \& Pozzebon, 2015).

\section{(Chart 1)}

MICROCREDIT TRANSFERS FROM OFFICIAL SOURCES

\begin{tabular}{rrrrrr}
\hline \multicolumn{7}{c}{ Microcredit distribution 2009 - 2014 } \\
\hline Year & $\begin{array}{r}\text { up to R\$ } \\
5,000 \text { (USD } 5,000 \text { (USD } \\
1,300)\end{array}$ & $\begin{array}{r}\text { over R\$ 10,000 } \\
10,000 \text { (USD } \\
\text { (USD 2,600) }\end{array}$ & $\begin{array}{r}\text { Millions } \\
\text { (R\$) }\end{array}$ & $\begin{array}{r}\text { Number of } \\
\text { contracts }\end{array}$ \\
\hline 2009 & $68 \%$ & $19 \%$ & $13 \%$ & 654 & 109.319 \\
2010 & $66 \%$ & $20 \%$ & $14 \%$ & 602 & 97.330 \\
2011 & $86 \%$ & $8 \%$ & $6 \%$ & 738 & 286.455 \\
2012 & $86 \%$ & $10 \%$ & $3 \%$ & 593 & 268.819 \\
2013 & $69 \%$ & $23 \%$ & $8 \%$ & 563 & 133.329 \\
2014 & $68 \%$ & $22 \%$ & $10 \%$ & 346 & 82.855 \\
\hline
\end{tabular}

Source: Adapted from Cresol 2009; 2010; 2011; 2012; 2013b; 2014a.

\section{Second aspect: Product access}

The Cresol system board members understand that the access to financial products promotes financial inclusion and local development. Provided funds have different sources: part derives from several public lines, such as the National Program to Strengthen Smallholder Farming (Pronaf); Bank of Brazil (BB); and the National Bank for Economic and Social Development (BNDES) - these three make up about $70 \%$ of Cresol's total disbursements. The other part is formed by Cresol's own resources, collected from members' savings and spreads on government credit lines. Cresol's own resource credit lines are named solidarity credit and complement government lines of credit, in particular, uncovered non-productive financing areas such as housing, car, and personal loans at an average 2\% annual interest rate. (Gonzalez, Diniz, \& Pozzebon 2015).

Among transfers out of government resources, microcredit volume has suffered reductions in the last three years (Chart 1). However, Cresol has counterbalanced that effect through three different actions that improve product access. The first is by increasing the volume of funds originated from 
own sources - called solidarity credit - as well as its average disbursement value (Graph 1 and Graph 2).

\section{(Graph 1)}

\section{CRESOL'S OWN RESOURCES DISBURSEMENT}

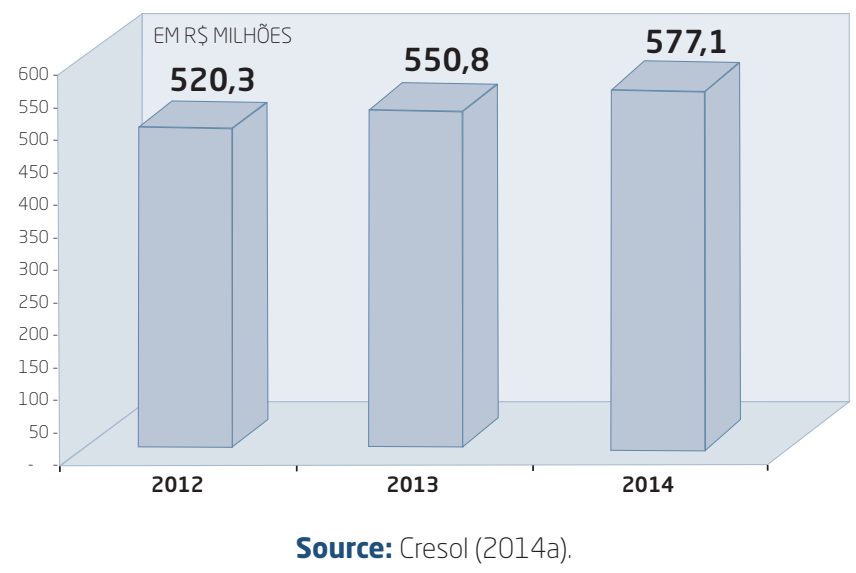

\section{(Graph 2) \\ AVERAGE DISBURSEMENT VALUE (PER MEMBER)}

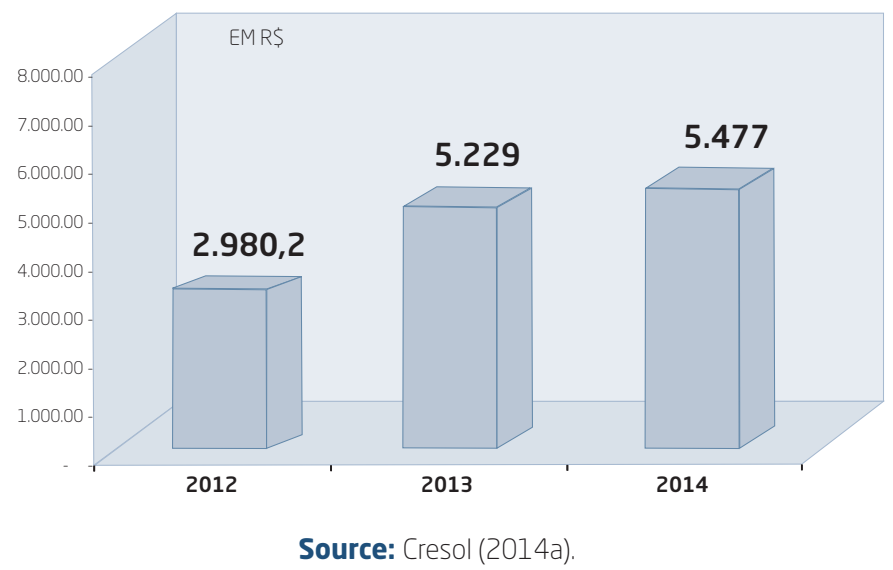

The second way through which Cresol improves access is by counterbalancing the reduction of official lines to microcredit by acting as an intermediary agent, transferring resources to PRONAF, which has experienced increases in the last five years (Chart 2). 


\section{(Chart 2)}

PRONAF RESOURCES RELEASED BY CRESOL

\begin{tabular}{ccccc}
\hline & $\begin{array}{c}\text { Funding } \\
\text { (Millions R\$) }\end{array}$ & $\begin{array}{c}\text { Investment } \\
\text { (Millions R\$) }\end{array}$ & Others & TOTAL \\
\hline 2009 & 160 & 139 & 42 & 340 \\
\hline 2010 & 164 & 106 & 25 & 295 \\
\hline 2011 & 194 & 116 & 38 & 348 \\
\hline 2012 & 262 & 144 & 81 & 487 \\
\hline 2013 & 328 & 178 & 50 & 556 \\
\hline 2014 & 369 & 258 & 43 & 670 \\
\hline
\end{tabular}

Source: Adapted from Cresol 2009; 2010; 2011; 2012; 2013b; 2014a.

The third way is by concentrating transfers of microcredit disbursements from external sources in values up to $\mathrm{R} \$ 5,000$, which could benefit a higher number of projects (Graph 3).

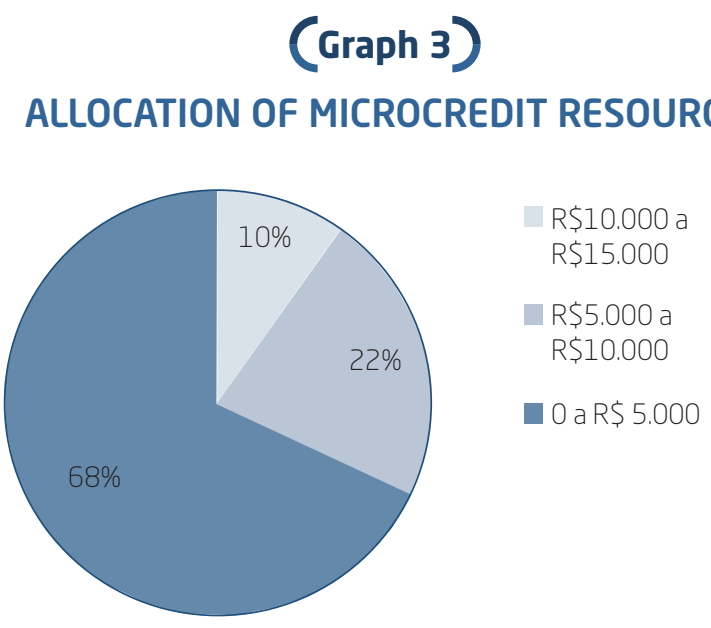

Source: Adapted from Cresol (2014a)

Cresol, as many other credit unions, has enhanced participation and access providing more resources and facilitating programs and projects. Product access has been assured also through local agents' proximity to clients, which will be discussed in the next topic. 


\section{Third aspect: The consumer's ability to properly use the product}

This aspect is achieved through financial education, held in three different fronts.

The first front is represented by local agents' action that reach people that are most in need of microcredit and with no access to traditional financial system. This process of transferring knowledge to farmers is part of the "Program of Community Agents of Development and Credit (PACDC). Through this program, each credit union has a credit committee and a group of Community Agents Development and Credit (PACDC), aimed at broadening social control and ensuring transparent and effective management. In addition, to reduce bureaucracy and decentralize credit management, agents assist in expanding the control of members by decentralizing the cooperative's attributions. They are the spokesmen for the demands and proposals raised by the community in the cooperative as well as the ones who transfer Cresol guidance to the associates (Cresol, 2015a).

The access is also made available by training small farmers making them able to offer their products in conditions that bring them economic returns. They receive information about how to participate in government biddings and offer their products, such as in the bidding to supply "The School Feeding Program" (PNAE); and to the "Food Acquisition Program" (PAA), where the government should buy food to offer to people in famine situations. They are also oriented to enter "The Family Farm Support Price Program" (PGPAF), to have their products bought by a fair price and the "Guarantee Program for Agriculture and Livestock Activities" (PROAGRO), to have a subsidized crop insurance linked to PRONAF Funding loans (Cresol, 2015b).

The second front is formed by credit analysts, actors that contribute to financial education, encouraging income and employment diversification by multiplying knowledge. They are responsible for assisting members prior to and during the entire loan term. Credit analysts also participate actively in the evaluation of debt restructuring and its rescheduling (Gonzalez, Diniz, \& Pozzebon 2015).

The third front is provided by INFOCOS (Training Institute of Solidarity Cooperatives), created by Cresol in 2005. INFOCOS train credit union workers, members and their families. Knowing and understanding how to organize the solidarity cooperative activities, farmers can actively participate in their cooperative routine. The agents foster discussions on the role of credit as a tool for building a sustainable production system for family 
production units, with the adoption of technologies that allow the farmer to develop their projects without affecting the balance of nature. The courses are provided to workers and to members and their families.

\section{Fourth aspect: The atmosphere around the operations of microfinance institutions and banks}

Regarding this aspect, we considered the evolution and influence of legislation and partnerships shaping a responsible microfinance environment.

Brazilian regulations concerning credit unions have existed since the publication of the Legislative Branch Decree No. 979, on January 6, 1903, which allowed the unions to organize themselves as rural banks, production and consumption cooperatives. However, the legal status of cooperatives in Brazil was only approved in 1971 - Law No. 5764. Moreover, the credit union sector began to take shape only with the promulgation of the Constitution of 1988 and Civil Code from 2002. Both regulatory frameworks gave legal certainty to the subject, consolidating the institution and access to members and users.

Another relevant milestone in financial inclusiveness was the Resolution No. 3.106/03 in which the National Monetary Council rescued and standardized the system of free admission - broadening the possible ways of association, allowing that one credit union be formed by individuals from different professional fields.

On August 5, 2015, Resolution 4,434/2015 was issued, which, according to Pinheiro Neto Advogados (2015), contains the following main points: new classification of individual credit unions; minimum limits of paid-in capital, equity, regulatory capital and governance; and establishment of processes, operating authorization and termination of credit unions.

Besides legislation, another factor interfering with the credit union environment and therefore with financial inclusion is the establishment of partnerships. Partnerships with private and public banks, as well as with other institutions, influence the volume of funds Cresol grants to its members and users. In addition, partners seek to build other policies that meet the needs of members in several areas. Partnerships may be local, national or international (Cresol, 2014b).

Regarding national partnerships, the Cresol system has agreements with the public banks, such as the National Bank for Economic and Social Development (BNDES); Banco do Brasil; and the Regional Development Bank (BRDE - Banco Regional de Desenvolvimento). They provide funds 
to national programs or fund Cresol projects, such as projects to create new units around the country. Cresol also has a partnership with the Ministry of Agrarian Development, Ministry of Agriculture and Supply, Ministry of Finance, cities and other government agencies.

International Partnerships are also part of the history of Cresol Baser. The Revolving Credit Fund, granted by German NGO Misereor, was responsible for the first loans made to farmers in the Southwest and Midwest regions of Paraná. There is also a partnership with the Belgian government to support a project of audit structuring, classification of cooperatives and development of the Intranet system, and with Rabobank from Netherlands, aiming to support the development of management and control systems in individual cooperatives (Cresol, 2014b).

\subsection{Data analysis}

The data analysis was based on inductive theorizing (Corley \& Gioia, 2004) and was carried out in three stages. We followed an analytical procedure based on the identification of clearly delineating themes and aggregate theoretical dimensions. Table 2 presents the data structure and illustrates the first order concepts and second order themes generated by the analysis.

In the first stage, we analysed interview transcriptions, research notes and documents, identifying the most granular themes that gave birth to the first-order themes. At this stage, we aimed at providing an overall understanding of the key aspects through which the products and services were designed and offered. As such, we organized the data, identifying all the relevant themes mentioned by interviewees as well as data from the other sources. Two researchers repeated the process in order to confirm the identification of the themes as well as the robustness of the model.

Once completing the first-order coding, we started the second stage of analysis, by engaging in axial coding (Strauss \& Corbin, 1998) to aggregate first-order themes into second order broad categories. In this phase, we were looking for themes that could provide a more abstract description of issues identified in the earlier phase. In the examination of themes and the aggregation into broader themes, we were theoretically supported by the extant literature on credit unions and proximity concept.

The three broader categories allowed us to summarize the elements that allow the emergence of a theoretical model for a responsible microfinance (Table 2). 


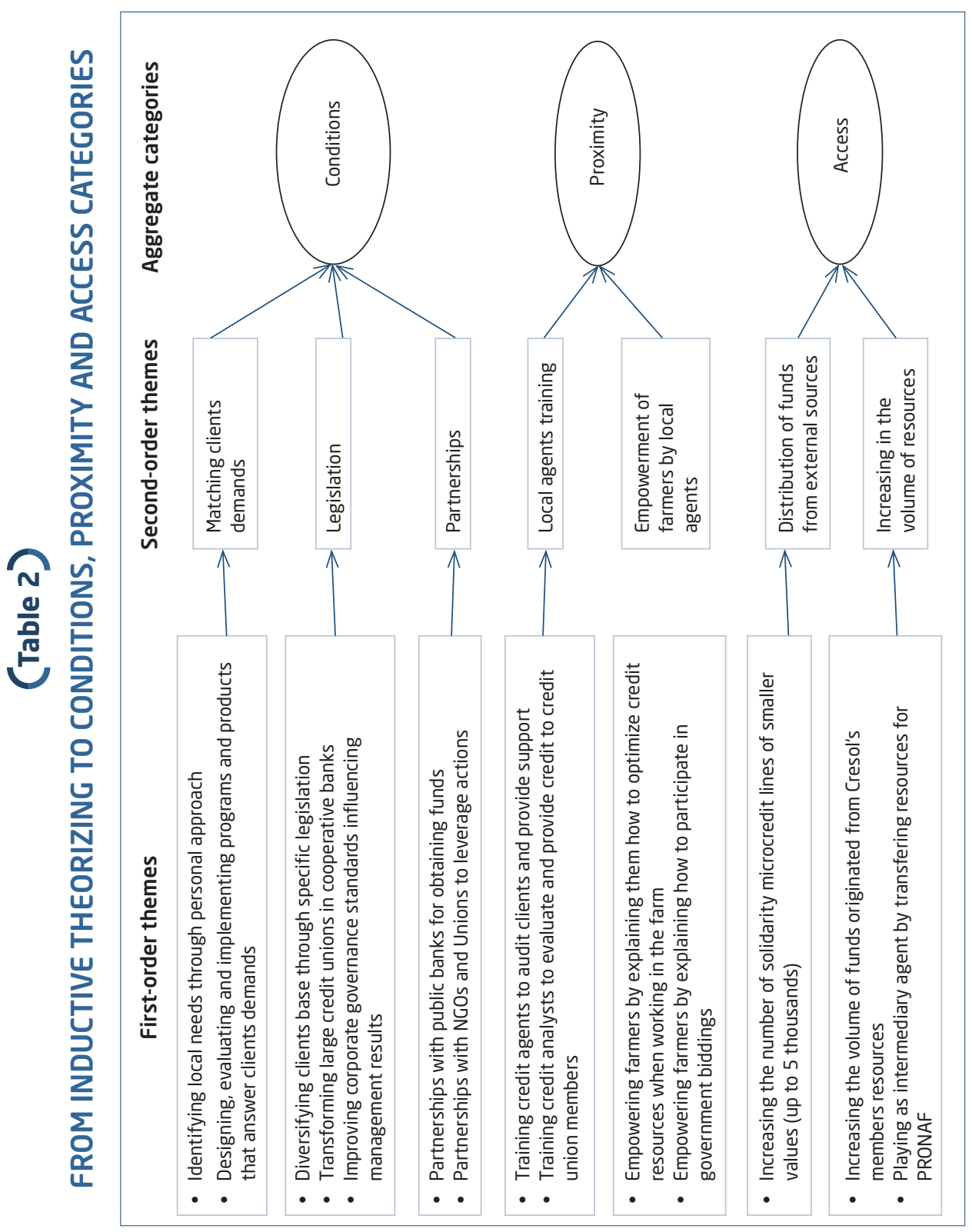




\subsection{Presentation of the results: a model of responsible microfinance factors}

Table 2 shows the emerging data structure after the process of our inductive coding (Corley \& Gioia, 2004), which were further organized in a model (Flowchart 1).

The first aggregate category is conditions, which is divided into three main themes: matching clients' demands, legislation, and partnerships. "Matching clients' demands" depends on the identification of local needs, design and implementation of proper products. Elements of legislation would contribute with the amplification of scope and size of credit unions. On the other hand, they would generate the need of governance instruments to better control the growth of credit unions. Partnerships would provide funds and conditions to leverage those organizations.

The second aggregate category is proximity, which is organized in two themes: training of local agents and empowerment of farmers by local agents. Through training, agents were also able to empower farmers by explaining them how to optimize credit resources and how to participate in government biddings.

Finally, the third aggregate category is access, which is a consequence of a better distribution of funds from external sources and increases in the volume of resources. The distribution of funds from external sources is a result of the increasing of the number of solidarity microcredit lines of lower values (up to 5 thousands) and also of the role of Cresol as an intermediary agent that transfers resources from PRONAF to clients.

The three broad categories discussed above gave origin to a model that implies relationships between them as showed in Flowchart 1.

As illustrated in Flowchart 1, there are three main dimensions in the model of inclusive microfinance; conditions, proximity, and access. The first is composed by conditions to improve access in responsible microfinance fashion at credit union organizations. Proximity is an element that makes the bridge between them.

We may infer many possible relationships between these three blocks that could interfere with the identified elements that compose the responsible financial model of a credit union. The three elements of the block of conditions may interfere on both elements of the second block (proximity). Some possibilities may be drawn. As credit unions identify and design new products, local agents training practices should change. As argued by Viswanathan, Sridharan, Gau, and Ritchie (2009), beyond market access 
and financial resources, consumers also need literacy for the successful use of products. The reciprocity from the second block may be observed when trained local agents receive new demands from empowered farmers and take them to credit union managements, contributing by providing information about ideal products to match the potential demand. This is a challenge that may be achieved as organizations seek out locally embedded individuals to act as agents to tap market communities (Kistruck, Sutter, Lount Jr., \& Smith, 2013).

\section{(Flowchart 1)}

\section{A MODEL FOR THE DYNAMICS OF RESPONSIBLE MICROFINANCE FACTORS}

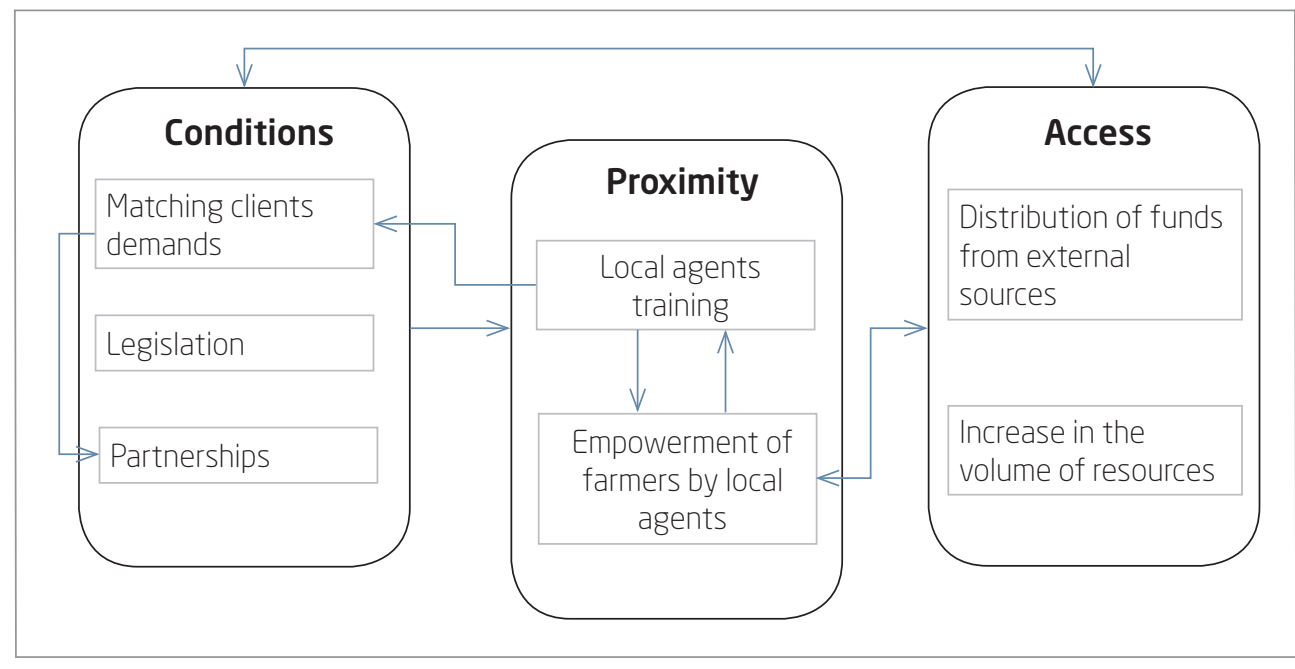

Source: Elaborated by the authors.

Relationships between the second and the third block are also likely. In the second block, we see empowered farmers that probably will have more chance to obtain access to available resources in block three. Reciprocity from the third to the second block is also possible. The empowerment of farmers may be achieved through the distribution of funds to a higher number of credit union clients and also through the increase in the volume of resources, which will logically vary respecting institutional and situational differences (Awal, 1996). In the case of Cresol, $68 \%$ of its own resources are up the value of $\mathrm{R} \$ 5,000$, which contributes to increase the number of benefited individuals. 
Financial inclusion may be achieved in a responsible way by considering the reciprocal implications between forces in the first and third blocks. Legislation may influence access, since it will likely provide more transparency to the credit union process, more frequent management renewal, and more careful assessment. In turn, more access will likely generate more participation, thus legislation should be updated when necessary. "Under the law, cooperative credit unions are relatively easy to set up" (Khavul, Chavez, \& Bruton, 2013, p. 34). Partnerships of credit unions with public and private banks, as well as with local and international organizations, may enhance resources volume and may determine the way resources are distributed (cf. Kistruck, Sutter, Lount Jr., \& Smith, 2013). On the other hand, changes on demand for new products influences the search for new partners that could offer new alternatives of product portfolios. As stated by Rivera-Santos, Rufín, and Kolk (2012), different types of organizations will provide different types of services. Firms, NGOs, government agencies, and local communities can all provide business resources, resources related to the objectives of the different partners.

Proximity is likely to influence product portfolios, since local agents make technical visits, identifying local clients' needs and their behavior in order to create ways to respond to them. Not only the need for new legislation and new product portfolios, but also the need for new partners may be a result of proximity with those clients (Webb, Kistruck, Ireland, \& Ketchen, 2010). What is remarkable is that proximity may also change as a result of interaction with clients. The result will likely be the emergence of new ways for local agents to approach and identify clients, the best way to distribute resources, and the real demand for increase in resources volume. In the end, proximity between the organization and consumers will define the best conditions to achieve access in a more responsible financial inclusion. As stated by Búrigo (2006), proximity generates opportunities to improve the focus on clients. Moreover, the system enables the creation of networks that generate social capital and awakens economic initiatives that banks would not have the will to grant (Abramovay, in press).

\section{CONCLUSIONS}

The objective of this article was to discuss how a credit union could achieve microcredit demands in a responsible fashion, by identifying the real client's needs and understanding their behavior. 
The Cresol business model was until recently based on the Raiffeisen model, adopting a typically rural approach based on bonds and solidarity economy. The creation of Solcredi in 2014 - opening the possibility so that people other than Cresol members could have access to its funds - meant a quite significant conceptual shift of the Cresol business model from a pure Raiffeisen to one with pinches of Luzzatti's type. This shift brings some implications to the theme of responsible microfinance in regards to the four aspects we are investigating.

Regarding the first aspect, whether the organizations know the customer and their needs and therefore design and offer products and services that meet these needs, the implications are that as approaching a different public, the credit union will have to develop new methodologies and train new agents and credit analysts to contact this new public and properly analyze the collected information. As Fachini (2005) pointed out, these agents have an important role in the insertion of microcredit in a given community. Therefore, if Cresol wish to reach the urban audience, it is necessary to better understand its needs and behavior.

Different needs have been satisfied through the offer of a wide range of products, some of them funded by Federal Government through public banks, and others by Cresol itself, that has identified opportunities to grow by filing financial market gaps, through the creation of Solcredi and Habitasol, and also by offering its own resources to enhance microcredit funds. However the access goal may be achieved only when consumers become able to properly use the products, which is possible through financial education lead by local agents and through participation of members in the management of credit unions - a real challenge if we consider that Cresol is growing to other regions of the country, with different cultures.

Access also encompasses distribution and resource volumes. Distribution seems assured by provision of the higher percentage of low value loans (amounts up to $\mathrm{R} \$ 5,000$ ). The volume of resources has increased by transference of Pronaf resources or by Cresol's own resource granting, but is still a challenge that could be changed by partnerships with other suppliers.

The atmosphere around the operations of microfinance institutions and banks is strongly dependent on legislation that has recently changed towards the establishment of mechanisms of governance to assure more transparency of management and participation of members, something that will contribute with the Cresol Central expansion to other regions of the country.

All of these aspects were integrated in a model that considers reciprocal movements executed through the application of the proximity concept in 
credit unions, in order to promote a dynamic that respects the assumption of a responsible financial inclusion with regards to design, offer and access of products and services related to microcredit.

The practical contribution is made by the four aspects explained and exemplified, which may be adapted to become an assessment tool. Future studies may improve this tool with tests in other situations. From a theoretical perspective, the results of the analysis shed new light on the literature on responsible financial inclusion by confirming some of its assertions.

\section{REFERENCES}

Abramovay, R. (in press). Finanças de proximidade e desenvolvimento territorial no semi-árido brasileiro. In M. B. Cossío (Org.). Estrutura Agrária, Mercado de Trabalho e Pobreza rural no Brasil, 2003. Retrieved from http://www.bv.fapesp.br/pt/auxilios/60888/financas-de-proximidade-edesenvolvimento-territorial-no-semi-arido-brasileiro/

Armendáriz de Aghion, B. A, \& Morduch, J. (2010). The economics of microfinance. Cambridge, MA: MIT Press.

Auwal, M. A. (1996). Promoting microcapitalism at the service of the poor: The Grameen Model and its cross-cultural adaptation. Journal of Business Communication, 33(1), 27-49. doi 10.1177/002194369603300105

Banco Central do Brasil (2015). Relatório de Inclusão Financeira. Retrieved from http://www.bcb.gov.br/Nor/relincfin/RIF2015.pdf

Banco Central do Brasil (2015a). Panorama do microcrédito Departamento de Monitoramento do Sistema Financeiro. Retrieved from https://www.bcb.gov.br/ Nor/relincfin/SerieCidadania_1panorama_micro.pdf

Banco Central do Brasil (2015b). Discurso do Ministro Alexandre Tombini, Presidente do Banco Centraldo Brasil na abertura do evento Novo Ciclodo Cooperativismo de Crédito no Brasil. Retrieved from http://www.bcb.gov.br/pec/appron/apres/Discurso\%20 do\%20presidente\%20Alexandre\%20Tombini\%20-\%20Novo\%20Ciclo\%20 Cooperativas\%20de\%20Credito\%20no\%20Brasil\%20-\%2005082015.pdf

Banerjee, A., Duflo, E., Glennerster, R., \& Kinnan, C. (2013). The miracle of microfinance? Evidence from a randomized evaluation (Working Paper No. 13-09). MIT, Cambridge, MA.

Búrigo, F.L. (2006). Finanças e solidariedade: uma análise do cooperativismo de crédito rural no Brasil (Doctoral dissertation). Universidade Federal de Santa Catarina, Florianópolis, SC, Brazil. 
Centre for the Study of Financial Innovation (CSFI) (2014). Microfinance banana skins 2014. Retrieved from http://www.citi.com/citi/microfinance/ data/2014_microfinance_banana_skins.pdf

Chaves, A. (2004). As Cooperativas podem Revolucionar o Microcrédito, publicação especial sobre cooperativas. Belo Horizonte, MG: SEBRAE.

Corley, K. G., \& Gioia, D. A. (2004). Identity ambiguity and change in the wake of a corporate spin-off. Administrative Science Quarterly, 49(2), 173-208. Cresol (2009). Relatório de atividades e balanço social. Retrieved from http:// www.cresol.com.br/site/upload/downloads/96.pdf

Cresol (2010). Relatório de atividades e balanço social. Retrieved from http:// www.cresol.com.br/site/upload/downloads/97.pdf

Cresol (2011). Relatório de atividades e balanço social. Retrieved from http:// www.cresol.com.br/site/upload/downloads/98.pdf

Cresol (2012). Relatório de atividades e balanço social. Retrieved from http:// www.cresol.com.br/site/upload/downloads/137.pdf

Cresol (2013a). Sistema Cresol-Como nos organizamos. Retrieved from http:// www.cresol.com.br/site/conteudo.php?id=2

Cresol (2013b). Relatório de atividades e balanço social. Retrieved from http:// www.cresol.com.br/site/upload/downloads/189.pdf

Cresol (2013c). Crédito do Solcredi muda a realidade dos empreendedores e realiza sonhos. Retrieved from http://www.cresol.com.br/site/notindividual. php?id=835\#.VlzsnNKrTcc

Cresol (2014a). Relatório de atividades e balanço social. Retrieved from http:// www.cresol.com.br/site/upload/downloads/209.pdf

Cresol (2014b). Central Baser Parceiros. Retrieved from http://www.cresol. com.br/site/conteudo.php?id=30

Cresol (2015a). Cresol juntos somos fortes. Agentes comunitários de desenvolvimento e crédito. Retrieved from http://www.cresol.com.br/site/ind_programas. php? id $=\mathrm{MQ}==$

Cresol (2015a). Cresol juntos somos fortes. Produtos e serviços - financiamentos. Retrieved from http://www.cresol.com.br/site/conteudo.php?id=32

The World Bank (2012). Measuring financial inclusion: The global findex database, policy research (Working Paper No. 6025). Washington, DC: Demirguc-Kunt, A., \& Klapper, L.

Eisner, E. W. (1991). The enlightened eye: Qualitative inquiry and the enhancement of educational practice. New York, NY: Macmillan. 
Fachini, C. (2005). Sustentabilidade financeira e custos de transação em uma organização de microcrédito no Brasil (Master's thesis). Universidade de São Paulo (USP), Piracicaba, SP, Brazil.

Fonseca, C. E. C., Meirelles, F. S., \& Diniz, E. H. (2010). Tecnologia bancária no Brasil - Uma história de conquistas, uma visão de futuro. São Paulo, SP: FGV.

Gonzalez, L. Diniz, E., \& Pozzebon, M. (2015). The value of proximity finance: How the traditional banking system can contribute to microfinance. Innovations, 10(1-2), 125-137. doi 10.1162/inov_a_00233

Gonzalez, L. E., \& Brito, M. G. F. (2013, September). Microcrédito nas cooperativas: Um estudo exploratório. Proceeding conducted at the meeting of the XXXVII Encontro da ANPAD - EnANPAD, Rio de Janeiro, RJ, Brazil.

Gonzalez, L.; Moser, R. M. B. (2015). Green microfinance: The case of the Cresol System in Southern Brazil. Revista de Administração Pública, 49(4), 1039-1058. doi 10.1590/0034-7612134039

Helms, B. (2006). Access for all: Building inclusive financial systems. Consultative Group to Assist the Pour (CGAP), Washington, DC. Retrieved from http://www.cgap.org/publications/access-all-building-inclusive-financialsystems

Hulme D., \& Arun, T. (2011). What's wrong and right with microfinance-missing an angle on responsible finance? doi 10.2139/ssrn.1895297

Kalliala, O. (2016). Credit union correspondents and financial inclusion in Brazil an explorative study (Doctoral dissertation). Fundação Getúlio Vargas (FGV), São Paulo, SP, Brazil.

Karlan, D. S. (2007). Social connections and group banking. The Economic Journal, 117(517), 52-84. Retrieved from http://onlinelibrary.wiley.com/ doi/10.1111/j.1468-0297.2007.02015.x/abstract

Khavul, S., Chavez, H., \& Bruton, G. D. (2013). When institutional change outruns the change agent: The contested terrain of entrepreneurial microfinance for those in poverty. Journal of Business Venturing, 28(1), 30-50. doi 10.1016/j.jbusvent.2012.02.005

Kistruck, G. M., Sutter, C. J., Lount Jr., R. B., \& Smith, B. R. (2013) Mitigating principal-agent problems in base-of-the-pyramid markets: An identity spillover perspective. Academy of Management Journal, 56(3), 659-682. doi 10.5465/amj.2011.0336

Ledgerwood, J., Earne. J., \& Candance, N. (2013). Microfinance in 2013. In J. Ledgerwood, J. Earne., \& N. Candance (Eds.). The new microfinance handbook: A financial market system perspective. Washington, DC: The World Bank. 
Lhacer, P. M. (2012). Cooperativas de Credito e formação de taxas de juros nas operações bancárias: tese e evidências empíricas para o Brasil (Doctoral dissertation). Fundação Getúlio Vargas, São Paulo, SP, Brazil.

McKillop, D. G., \& Wilson, J. O. S. (2011). Credit Unions: A theoretical and empirical overview. Financial Markets, Institutions \& Instruments, 20(3), 79-123. doi 10.2139/ssrn.1702782

Meinen, Ê. (2013). As instituições financeiras cooperativas e os 10 anos de livre admissão de associados. Retrieved from http://www.bancoob.com.br/ imprensa/as-instituicoes-financeiras-cooperativas-e-os-10-anos-de-livreadmissao-de-associados

Ministério do Desenvolvimento Agrário (MDA). (2015). Pronaf - Condições Do Crédito Rural - Plano De Safra 2015/2016. Retrieved from http:// www.mda.gov.br/sitemda/sites/sitemda/files/user_arquivos_627/ Condi\%C3\%A7\%C3\%B5es\%20do\%20Cr\%C3\%A9dito\%202015-2016̄.pdf

Monzoni Neto, M. P. (2006). Impacto em renda do microcrédito: uma investigação empírica sobre geração de renda do crédito popular solidário (São Paulo Confia), no município de São Paulo (Doctoral dissertation). Fundação Getúlio Vargas (FGV), São Paulo, SP, Brazil.

Morduch, J. (1999). The Microfinance Promise. Journal of Economic Literature, 37(4), 1569-1614. doi 10.1257/jel.37.4.1569

Organisation for Economic Co-operation and Development (OECD) (2004). OECD Financial Education Project: Background and implementation. Retrieved from http://www.oecd.org/finance/financial-education/ oecdfinancialeducationprojectbackgroundandimplementation.htm

Pimentel, V., \& Kerstenetzky, C. L. (2008). Microcrédito: Por que os bancos privados não bancam? Universidade Federal Fluminense (Working Paper No. 242). Niterói, RJ, Brazil.

Pinheiro, M. A. H. P. (2008). Cooperativas de crédito: História da evolução normativa no Brasil (6 ed.). Brasília, DF: BCB.

Pinheiro Neto Advogados (2015). Novo marco regulatório de cooperativas de crédito. Retrieved from http://www.pinheironeto.com.br/Pages/imprensadetalhes.aspx? $\mathrm{nID}=89$

Reinhard, H. S. (2008) Microfinance, commercialisation and ethics. Working paper series: finance \& accounting, 194. Retrived from http://www. microfinancegateway.org/sites/default/files/mfg-en-paper-microfinancecommercialisation-and-ethics-sep-2008_0.pdf

Righetti, C. C. B. (2008). Efeitos do microcrédito na geração de renda em microempreendimentos: Avaliação de impacto do programa Real Microcrédito (Doctoral dissertation). Fundação Getúlio Vargas (FGV), São Paulo, SP, Brazil. 
Rivera-Santos, M., Rufín, C., \& Kolk, A. (2012). Bridging the institutional divide: Partnerships in subsistence markets. Journal of Business Research, 65(12), 1721-1727. doi 10.1016/j.jbusres.2012.02.013

Singer, P. (2002) Introdução à economia solidária. São Paulo, SP: Fundação Perseu Abramo.

Stake, R. (2000). The case study method in social inquiry. In K. D. Norman, \& L. S. Yvona. The American tradition in qualitative research (Vol. II). Thousand Oaks, CA: Sage.

Strauss, A., \& Corbin, J. (1998). Basics of qualitative research: grounded theory, procedures and techniques (2 ed.). Newbury Park, CA: Sage.

Viswanathan, M., Sridharan, S., Gau, R., \& Ritchie, R. (2009). Designing marketplace literacy education in resource-constrained contexts: Implications for Public Policy and marketing. Journal of Public Policy \& Marketing, 28(1), 85-94. doi 10.1509/jppm.28.1.85

Webb J. W., Kistruck G. M., Ireland R. D., \& Ketchen D. J. J. (2010). The entrepreneurship process in base of the pyramid markets: The case of multinational enterprise nongovernment. Entrepreneurship: Theory and Practice, 34(3), 555-581. doi 10.1111/j.1540-6520.2009.00349.x

\section{ABOUT THE AUTHORS}

\section{TANIA PEREIRA CHRISTOPOULOS}

$\mathrm{PhD}$ from the Department of Business Administration,

Fundação Getúlio Vargas (FGV).

Assistant Professor at the School of Arts, Sciences and Humanities,

Universidade de São Paulo (USP).

Rua Arlindo Bettio, 1000 - Ermelino Matarazzo - São Paulo - SP - Brasil - CEP 03828-000

E-mail: tchristo@gmail.com

\section{LAURO GONZALEZ}

PhD from the São Paulo School of Economics,

Fundação Getúlio Vargas (FGV).

Professor at the Department of Finance,

Fundação Getúlio Vargas (FGV).

Rua Itapeva, 474, Bela Vista - São Paulo - SP- Brasil - CEP 01332-010

E-mail: lauro.gonzalez@fgv.br 